waardigheid. In zijn kerstpreek verwees patriarch Michel Sabbah naar de nieuwe situatie en riep hij allen op tot broederlijke solidariteit en onderlinge verzoening.

President Yasser Arafat nam eveneens deel aan de viering van het orthodoxe kerstfeest, in de nacht van 6 op 7 januari 1996.

Frans Bouwen (Jeruzalem)

\section{DE ASSYRIËRS IN DE VERENIGDE STATEN}

\section{Voorgeschiedenis}

Van de naar schatting 419.000 Assyriërs wonen er zo'n 110.000 in de Verenigde Staten en Canada, bijna net zoveel als op dit moment in Irak. ${ }^{1}$ De grootste gemeenschap van Assyriërs buiten het Midden-Oosten verdient daarom aparte aandacht. De gemeenschap in de Verenigde Staten is ook een van de oudste gemeenschappen buiten het MiddenOosten. $\mathrm{Al}$ aan het einde van de negentiende eeuw vertrokken de eerste Assyriërs naar Amerika om daar te gaan studeren, en in heel wat gevallen besloten zij uiteindelijk ook daar te blijven. Chicago, nog steeds de stad met de grootste Assyrische gemeenschap, was daarbij een belangrijk eindpunt. $\mathrm{Na}$ de

${ }_{1}$ De aantallen die in verschillende publicaties gegeven worden, verschillen nogal, soms omdat te hoge aantallen de ronde doen, soms ook omdat ook chaldeeën (de met de Rooms-Katholieke Kerk geünieerde 'Assyriërs', ook Assyro-chaldeeën genoemd), Syrisch-orthodoxen en soms zelfs maronieten tot de 'Assyriërs' gerekend worden. In deze kroniek staat 'Assyriërs' alleen voor de niet met Rome geünieerde Oost-Syriërs, de 'Nestorianen'. De cijfers in deze kroniek, evenals veel van de informatie betreffende kerkelijke zaken, zijn afkomstig van J.F. Coakley, 'The Church of the East since 1914', binnenkort te verschijnen in Bulletin of the John Rylands University Library of Manchester. Daarnaast is gebruikgemaakt van nog ongepubliceerd onderzoek naar de Assyriche gemeenschap in Chicago, uitgevoerd door Daniel Wolk. 
Eerste Wereldoorlog nam het aantal Assyrische immigranten belangrijk toe, net zo als na de Tweede Wereldoorlog. Meer recentelijk hebben de burgeroor$\log$ in Libanon (waar veel Assyriërs na de Eerste Wereldoorlog terecht waren gekomen), de oorlog tussen Iran en Irak en de Golfoorlog veel Assyriërs doen besluiten naar Amerika te vertrekken. Het duurde echter tot ruim na de Tweede Wereldoorlog voordat de kerkelijke leiding van de Assyrische Kerk zich actief ging bezighouden met de opbouw van het kerkelijk leven in de Amerikaanse diaspora. Tot aan die tijd werden Mar Shimun, die in 1920 als elfjarige tot patriarch was gewijd, en Lady Surma, zijn tante die de feitelijke leiding in handen had, in beslag genomen door alle verwikkelingen rond een eventueel nationaal tehuis voor de Assyriërs in het Midden-Oosten of elders. Vanaf 1948 lijkt de kwestie van een Assyrisch thuisland voor de patriarch niet langer een reële optie te zijn, en vanaf die tijd werd de opbouw van de kerk weer met kracht aangevat.

In de Verenigde Staten was de patriarch op dat moment de enige bisschop. De belangrijkste parochies waren Chicago, New Britain (Connecticut), Philadelphia, Yonkers (New York), Flint (Michigan), Gary (Indiana), San Francisco en Turlock (Californië). Mar Shimun vestigde zich in San Francisco. In 1964 werd voor het eerst weer een bisschoppelijke synode gehouden, mogelijk gemaakt door het feit dat bisschop Mar Khananisho van Irak voor medische behandeling naar de VS was gekomen. Deze synode besloot tot verschillende hervormingen, waaronder de aanpassing aan de Gregoriaanse kalender.
Deze aanpassing aan het westerse christendom vormde één van de zaken die in 1968 aangevoerd werden door opposanten van de patriarch om hun afscheiding te rechtvaardigen. Het is echter aannemelijk dat oude tegenstellingen tussen verschillende stammen een belangrijker rol speelden in dit conflict. Vanaf deze tijd bestaat er naast de 'Heilige Apostolische Katholieke Assyrische Kerk van het Oosten', zoals de kerk zich de laatste jaren is gaan noemen, de 'Oude Kerk van het Oosten', die zich houdt aan de oude kalender. De laatste groep heeft alleen in Irak een redelijke aanhang, in de Verenigde Staten is hun aantal klein. In de jaren 70 doemden nieuwe problemen op toen de patriarch bekend maakte dat hij ging trouwen. Dit leidde ertoe dat hij door de bisschoppen werd afgezet, maar voordat de discussie tussen de bisschoppen en de patriarch beëindigd was, werd Mar Shimun in 1975 vermoord. Of de moordenaar, een Assyriër, door nationalistische of kerkpolitieke redenen gedreven werd is nooit duidelijk geworden.

In 1976 werd de huidige patriarch gekozen: Mar Dinkha IV. Afkomstig uit Irak, zag hij zich door de oorlog tussen Irak en Iran gedwongen ook naar de Verenigde Staten te vertrekken, waar hij zich vestigde in Chicago. Mar Dinkha probeert, in navolging van de vorige patriarch, zoveel mogelijk samen te werken met de overheden van de landen in het Midden-Oosten waar zich Assyrische gemeenschappen bevinden. In die lijn deed hij, samen met de bisschoppen, een oproep aan de regering van de Verenigde Staten om het embargo tegen Irak op te heffen. 


\section{Kerkelijk leven}

Onder de leiding van Mar Dinkha is de Assyrische Kerk zich zowel naar binnen als naar buiten actiever gaan opstellen. $\mathrm{Er}$ is een actief gemeenschapsleven rond de parochies. De Verenigde Staten zijn op dit moment verdeeld in vijf bisdommen, waarvan die van Chicago, met ongeveer 60.000 leden verdeeld over drie parochies, de grootste is. Dit is het bisdom van de patriarch. In de westelijke Verenigde Staten zijn zeven parochies (San José, San Francisco, Modesto, Turlock, North Hollywood, Fullerton and Phoenix), met in totaal 24.000 leden. Hier is op dit moment geen bisschop. Mar Aprim Khamis is de bisschop van de oostelijke Verenigde Staten, bestaande uit vier parochies (Detroit, Flint, Yonkers, New Britain) met 15.000 leden. Mar Bawai Soro, officieel de bisschop van het bisdom Seattle, bestaande uit twee parochies (Seattle en Sacramento) met samen 1000 leden, is grotendeels vrijgesteld voor het onderhouden van de interkerkelijke relaties. In Canada geeft Mar Emmanuel Josep de leiding aan vier parochies en twee 'missies' met zo'n 10.000 leden. Mar Daniel Yacob is de bisschop van de ongeveer 3000 Assyriërs in Canada en in de Verenigde Staten die vasthouden aan de oude kalender.

De belangrijkste ontwikkelingen in de kerk betreffen de interkerkelijke contacten. Niet alleen is het contact met de Rooms-Katholieke Kerk aanmerkelijk verbeterd, hetgeen onder andere is gebleken uit de gemeenschappelijke christologische verklaring van december 1994 (waarover in Het Christelijk Oosten al eerder bericht is ${ }^{2}$ ), maar ook met de andere oosterse kerken, zoals de
Syrisch-Orthodoxe Kerk. De consultaties, georganiseerd door Pro Oriente te Wenen spelen hierbij een belangrijke rol. In de Verenigde Staten zijn vooral de betere relaties met de Chaldeeuwse Kerk van belang. Op 29 november 1996 is in Southfield (Michigan, VS) een gezamenlijke Assyrisch-chaldeeuwse verklaring afgegeven. Hierin wordt door de patriarchaten van beide kerken voorgesteld op allerlei terreinen nauwer te gaan samenwerken, zowel plaatselijk, in de parochies, als nationaal en internationaal, onder andere op het terrein van de opleiding van de geestelijkheid en de gezamenlijke inzet voor het behoud van de eigen kerkelijke en culturele identiteit. Van Assyrische zijde is het Mar Bawai Soro die de commissie voor interkerkelijke contacten leidt. Hij geeft ook het tijdschrift The Messenger (Izgada) uit, waarin deze nieuwe ontwikkelingen worden bijgehouden.

\section{Cultuur}

De Assyriërs in de Verenigde Staten zijn goed georganiseerd. Naast de Assyrian American National Federation (AANF), die elke twee jaar een grote conventie organiseert en het tijdschrift The Assyrian Star uitgeeft, zijn er talloze plaatselijke verenigingen, die net als de AANF ten doel hebben de Assyriërs te verenigen en hun taal en cultuur te behouden. Veel van deze organisaties - net als de AANF - besteden veel tijd en aandacht aan de identificatie met de oude Assyriërs. In

2 A. Davids, 'De Syrische dialoog', CO, 47 (1995), pp. 213-233. Zie ook id. 'De Syrische dialoog: Tweede ronde', $C O, 48$ (1996), pp. 310-313. 
sommige gevallen leidt dat tot de expliciete roep om een eigen 'thuisland', liefst in Noord-Irak, maar het lijkt erop dat het overgrote deel van de Assyriërs daar niet veel meer in ziet. Wel wordt er veel aandacht besteed aan de situatie in Koerdistan en er wordt in Amerika veel geld verzameld voor de Assyrische christenen aldaar. Ook de politieke partijen van de Assyriërs in het Midden-Oosten krijgen praktische en geldelijke ondersteuning uit Amerika.

Een belangrijk aspect van de Assyrische identiteit, naast de kerkelijke banden, is de gemeenschappelijke taal. De immigranten van na de Tweede Wereldoorlog gebruiken hun moedertaal, het 'Soeret', een modern Aramese taal, nog volop. Er wordt tamelijk veel aandacht besteed aan het leren lezen en schrijven van deze taal, iets dat de recente immigranten uit Irak in veel gevallen niet geleerd hebben. Daarnaast wordt de kinderen klassiek Syrisch, een oudere variant van het Aramees, geleerd, omdat de liturgie van de Assyrische Kerk nog steeds, ook in de VS, in deze taal gelezen wordt. De preek is meestal in het Soeret en in een enkel geval in het Engels (er zijn een paar parochies waar een aantal leden van oorsprong niet Assyrisch zijn), terwijl er ook wat gezangen in het Soeret in gebruik zijn. Er wordt tamelijk veel in het Soeret gepubliceerd, zowel door kleine Assyrische uitgeverijtjes als door privé-personen. Naast historische werken is vooral de hoeveelheid poëzie opvallend. Ook worden regelmatig negentiendeeeuwse zendingspublicaties herdrukt, meestal grammaticale of historische werken. Degenen die zich hiervoor inzetten zijn in veel gevallen eerste- of tweedegeneratie immigranten, die in de jaren
70 en 80 naar Amerika zijn gekomen. De derde- en vierde-generatie immigranten spreken meestal geen Soeret meer en zijn vaak in vergaande mate geassimileerd. Onder de recente immigranten ligt het percentage huwelijken met niet-Assyriërs op ongeveer tien procent, hetgeen er op wijst dat er nog een tamelijk sterke gerichtheid is op de eigen culturele groep. Onder de eerste generatie immigranten lag dit percentage waarschijnlijk hoger, vooral bij gebrek aan geschikte partners uit de eigen groep. In het verlengde van de aandacht voor de eigen taal ligt de meer algemene aandacht voor de eigen cultuur. Er zijn dans- en toneelverenigingen waar oude tradities in ere worden gehouden. De Assyrian Academic Society organiseert lezingen over allerlei onderwerpen die de Assyrische cultuur en geschiedenis betreffen. Deze lezingen worden zowel door specialisten van buiten als door eigen mensen gegeven en trekken veel belangstelling. Ook hun blad, de Journal of the Assyrian Academic Society, draagt bij aan de bezinning op de eigen cultuur. De nieuwe mogelijkheden op Internet zijn door Assyriërs aangegrepen om wereldwijd contact te houden en informatie uit te wisselen, variërend van het laatste nieuws uit Noord-Irak tot Assyrische recepten.

In een stad als Chicago zijn het de eerste- en tweede-generatie immigranten die de kern van de Assyrische gemeenschap vormen. Meestal zijn het de goed opgeleide jongeren uit deze recente immigratiegolf die de leiding hebben. In sommige wijken is een belangrijk deel van de middenstand in Assyrische handen, van kruidenier tot videoverhuur, terwijl men ook voor een arts, 
tandarts of advocaat niet buiten de eigen kring hoeft te treden. Het nieuwjaarsfeest, op 1 april, wordt met een grote publieke optocht gevierd, waarmee de Assyrische gemeenschap, in navolging van de vele andere immigrantengemeenschappen in de Verenigde Staten, herkenbaar naar buiten treedt.

\section{Tot slot}

De Assyrische gemeenschap in de Verenigde Staten maakt de indruk een bloeiende gemeenschap te zijn, ondanks de interne discussies over de positie van het Assyrisch nationalisme en de rol van de kerk. Hoewel de eerste immigratiegolven laten zien dat het op de lange duur waarschijnlijk moeilijk zal zijn de eigen spreektaal te behouden in een land waar het Engels dominant is, geeft het actieve gemeenschapsleven hoop op een meer permanente voortleving van de Assyrische cultuur in de Verenigde Staten.

H.L. Murre-van den Berg (Leiden)

\section{DE SERVISCH- ORTHODOXE KERK}

De kroniek over de Servisch-Orthodoxe Kerk werd tot nu toe in dit tijdschrift onder de kop 'Servië' gepubliceerd. Helemaal juist was dat eigenlijk niet, aangezien de grenzen van de jurisdictie van het Servische patriarchaat aanmerkelijk verder reiken dan de grenzen van de Republiek Servië. In Bosnië-Hercegovina en Kroatië is de Servisch-Orthodoxe Kerk sinds vele eeuwen geworteld en georganiseerd in 10 bisdommen. Ook Montenegro en Macedonië vallen onder de jurisdictie van het Servische patriarchaat. Weliswaar heeft de MacedoonsOrthodoxe Kerk de autokefalie uitgeroepen, maar deze wordt door het Servische patriarchaat niet erkend. En ook in de beweging voor autokefalie in Montenegro wordt een grote bedreiging voor de eenheid van de kerk gezien. Door de oorlog in Slovenië, Kroatië en BosniëHercegovina van '91-95 hebben zich dramatische en tragische verschuivingen voorgedaan in de getalsverhoudingen tussen de verschillende bevolkingsgroepen, die bepalend kunnen zijn voor het voortbestaan van de Orthodoxe Kerk in Bosnië-Hercegovina en Kroatië. Eén van de grootste problemen voor de kerk op dit moment is hoe het pastorale werk in de nieuwe staten kan worden voortgezet en hoe de eenheid van het Servische patriarchaat kan worden gewaarborgd. Omdat deze zaken ook in deze kroniek

1 Deze kroniek gaat over 1996. Voor de vorige kroniek zie CO, 48 (1996), 1-2, pp. 99-109. 